\title{
Construction of Dry Cover System for Prevention of Acid Mine Drainage at Mine Waste Dump in Open Cast Coal Mines, Indonesia
}

\author{
Shinji Matsumoto1* ${ }^{*}$, Hideki Shimada1, Takashi Sasaoka1, Ginting J. Kusuma², \\ Rudy S. Gautama ${ }^{2}$ \\ ${ }^{1}$ Department of Earth Resources Engineering, Kyushu University, Fukuoka, Japan \\ ${ }^{2}$ Department of Mining Engineering, Institute Technology Bandung, Bandung, Indonesia \\ Email: "matsumoto11r@mine.kyushu-u.ac.jp
}

Received 13 January 2016; accepted 13 February 2016; published 16 February 2016

Copyright @ 2016 by authors and Scientific Research Publishing Inc.

This work is licensed under the Creative Commons Attribution International License (CC BY). http://creativecommons.org/licenses/by/4.0/

(c) (i) Open Access

\begin{abstract}
Acid Mine Drainage (AMD) which occurs when sulfide minerals are exposed to water and oxygen with an excavation is one of the serious environmental problems in the world. A dry cover system is generally constructed in waste dump for the prevention of AMD in Indonesia by virtue of low cost and availability of waste rocks for a cover layer. However, the failure of the system caused by the lack of information related to the construction of cover system in mines, which leads to AMD, has been reported recently in Indonesia. In this study, the field investigation was conducted in pit and waste dump in open cast coal mine in Indonesia with the aim of obtaining the information on the construction of a cover layer and backfilling conditions of waste rocks in the waste dump. The rock samples taken in two areas of the mine were analyzed by geochemical analysis and sequential extraction with acids. The results indicated that Net Acid Producing Potential (NAPP) of the rocks in the waste dump down to $100 \mathrm{~cm}$ depth in both areas was from 10 to $30 \mathrm{~kg} \mathrm{H}_{2} \mathrm{SO}_{4} /$ ton, suggesting that Potentially Acid Forming (PAF) was backfilled in a cover layer. The backfill of PAF was contrary to the concept of cover system, which caused the failure of constructing a cover layer. The cause of the failure was likely attributed to the shortage of cover rocks which are classified as Non Acid Forming (NAF) or the failure of proper placement of them by an operational problem in the areas. Moreover, the results of the extraction with acids suggested that the form of iron and sulfur has to be taken into account to discuss the occurrence of AMD.
\end{abstract}

"Corresponding author.

How to cite this paper: Matsumoto, S., Shimada, H., Sasaoka, T., Kusuma, G.J. and Gautama, R.S. (2016) Construction of Dry Cover System for Prevention of Acid Mine Drainage at Mine Waste Dump in Open Cast Coal Mines, Indonesia. Journal of Environmental Protection, 7, 160-169. http://dx.doi.org/10.4236/jep.2016.72014 
Keywords

Acid Mine Drainage (AMD), Dry Cover System, Open Cast Coal Mine, Indonesia

\section{Introduction}

The negative impacts on the nature of coal development by open cast mining have been reported with expansion of coal production recently in Indonesia. Acid Mine Drainage (AMD), which is a serious environmental problem, is attributable to the contact of sulfide minerals with water and oxygen in excavation activities in mining. This problem affects the nature in the field [1]; therefore, it has to be prevented within the operation of mines.

The generation of acidic water proceeds with the dissolution of sulfide minerals such as pyrite $\left(\mathrm{FeS}_{2}\right)$, followed by the reaction that $\mathrm{Fe}^{2+}$ changes into $\mathrm{Fe}^{3+}$ through oxidation by oxygen (Equations (1) and (2)) [2].

$$
\begin{aligned}
& \mathrm{FeS}_{2}+\frac{7}{2} \mathrm{O}_{2}+\mathrm{H}_{2} \mathrm{O} \rightarrow \mathrm{Fe}^{2+}+2 \mathrm{SO}_{4}^{2-}+2 \mathrm{H}^{+} \\
& \mathrm{Fe}^{2+}+\frac{1}{4} \mathrm{O}_{2}+\mathrm{H}^{+} \rightarrow \mathrm{Fe}^{3+}+\frac{1}{2} \mathrm{H}_{2} \mathrm{O}
\end{aligned}
$$

$\mathrm{Fe}^{3+}$ precipitates as ferric hydroxide $\left(\mathrm{Fe}(\mathrm{OH})_{3}\right)$ by reacting with water (Equation (3)), leading to red-brown color in acidic water. Additionally, $\mathrm{Fe}^{3+}$ oxidizes sulfide minerals and $\mathrm{Fe}^{2+}$ forms (Equation (4)).

$$
\begin{aligned}
& \mathrm{Fe}^{3+}+3 \mathrm{H}_{2} \mathrm{O} \rightarrow \mathrm{Fe}(\mathrm{OH})_{3}+3 \mathrm{H}^{+} \\
& \mathrm{FeS}_{2}+14 \mathrm{Fe}^{3+}+8 \mathrm{H}_{2} \mathrm{O} \rightarrow 15 \mathrm{Fe}^{2+}+2 \mathrm{SO}_{4}^{2-}+16 \mathrm{H}^{+}
\end{aligned}
$$

The chemical reaction continues until sulfide minerals are depleted, and produced $\mathrm{H}^{+}$decreases the $\mathrm{pH}$. Thus, it is important to prevent the contact of sulfide minerals with oxygen and water to prevent these reactions.

A dry cover system is a reliable method for prevention of exposure of sulfide minerals to oxygen and water in order to control AMD due to low cost and less works in comparison with the others [3] [4]. This system, especially using a soil cover, is generally adopted in open cast coal mines in Indonesia owing to the availability [5].

In this system, waste rocks are classified into Potentially Acid Forming (PAF), Non Acid Forming (NAF), or uncertain materials on the basis of the geochemical properties of rocks by conducting several geochemical analysis [6]-[8]. PAF is the main cause of AMD and NAF is utilized as cover materials in the system. PAF is separated from waste rocks as the cause of AMD through the classification. To measure the geochemical properties, Acid Base Accounting (ABA) test and Net Acid Generating (NAG) test are performed in mines [6] [7]. Waste rocks are classified by plotting Net Acid Generating (NAG) $\mathrm{pH}$ and Net Acid Producing Potential (NAPP) which are obtained by the tests [8]. PAF is backfilled in waste dump and covered with NAF after the classification in order not to expose PAF to water and oxygen in dry cover system for the prevention of AMD. The thickness of a cover layer is generally set at about from 1 to $5 \mathrm{~m}$ according to rock properties and required performance of a cover layer [5] [9]-[11]. If a cover layer fails to work after backfilling waste rocks in waste dump, AMD continues to be generated from the waste dump for a long time. Significant time and cost are required for the treatment of continual generation of AMD in the case. According to the previous studies [12], it was stated that the failure of cover system, which utilizes the moisture store-and-release concept in a cover layer, attributes to design of cover layer, lack of site-specific climate consideration, lack of control on materials that meet the design characteristic, proper placement and management of cover materials, and failure of vegetation. All of the reasons relate to construction process of a cover layer aimed at preventing the contact of PAF with water and oxygen in dry cover system as well as the system using store-and-release concept: it considers the balance of evaporation and precipitation to control water percolation in a cover layer [13] [14]. Lack of control on materials and proper placement and management of them is the most fundamental and important point for the construction of a cover layer in above all reasons. These points are useful for evaluating whether a cover layer is successfully constructed or not in the field in mines. The evaluation can, moreover, provide information helpful for successive construction of a cover layer in mining. However, the construction of a cover layer in open cast coal mines in Indonesia is evaluated in a few studies. Many open cast coal mines in Indonesia have been engaged on intro- 
ducing cover system to prevent AMD; though, there are several problems in construction of cover system in the mines [5] [15] [16].

In this study, field investigation and geochemical analysis with the rock samples taken in mines were performed with a focus on the amount of waste rocks and the geochemical properties of rocks in order to evaluate and obtain the information on the construction of a cover layer and backfilling conditions of waste rocks in waste dump in open cast coal mine in Indonesia.

\section{Material and Methods}

\subsection{Sampling}

A field survey was conducted with sampling of waste rocks in the coal mine in Indonesia with the objective of examining the conditions of construction of a cover layer and backfilling waste rocks in the waste dump. This mine is an open cast mine and one of the largest coal mines in Indonesia. The annual production has been around 10 million ton recently, and there is a trend toward an increase in the production. Most of the produced coals which consist of Sub-Bituminous and Lignite are used in domestic and exported to Asian counties. The average value of sulfur content in waste rocks is about $1 \%$, leading to AMD with the expansion of mining area. Waste rocks are backfilled in the waste dump in accordance with cover system after the classification of them into PAF and NAF following the standard proposed in 1997 for the prevention of AMD in this mine [6] [7]. In this research, a field survey was carried out with sampling rocks in the pits and in the waste dumps in two areas which were named as area I and II. The direct distance between the areas is about $5 \mathrm{~km}$. There is no great difference in climate conditions between the areas. It has taken more than a year since the waste dump was constructed in both areas. The occurrence of AMD from the waste dump was ever reported in the areas. $5 \mathrm{~m}$ of representative samples were collected in pit from each layer which is classified according to the lithology in the mine from the surface down to $140 \mathrm{~m}$ in each area. These samples were taken before excavation and not exposed to air. Additionally, 5 core samples were taken in the waste dump in area I and II using a 8-cm diameter hand auger DIK-100A-55 at $20 \mathrm{~cm}$ intervals down to $100 \mathrm{~cm}$ depth. The rock samples were packed in the plastic bag not to be oxidized after sampling and transported to the laboratory.

\subsection{Sample Analysis}

The samples were dried at $50^{\circ} \mathrm{C}$ for $48 \mathrm{~h}$ in a nitrogen atmosphere to supply to X-Ray Diffraction (XRD) and $\mathrm{X}$-Ray Fluorescent (XRF). Major minerals in the samples were analyzed using wide angle goniometer RINT 2100 XRD under the following condition: radiation $\mathrm{CuK} \alpha$, operating voltage $40 \mathrm{kV}$, current $26 \mathrm{~mA}$, divergence slid $1 \mathrm{deg}$, anti-scatter $1 \mathrm{deg}$, receiving slit $0.3 \mathrm{~mm}$, step scanning $0.050^{\circ}$, scan speed $2.000^{\circ} / \mathrm{min}$, scan range $2.000^{\circ}-65.000^{\circ}$.

They were analyzed by ABA test and NAG test to classify them into PAF or NAF by following the standard [6] [8]. ABA test was proposed in 1974, and it was modified by Sobek et al. in 1978 [6]. Acid Potential (AP) is calculated based on the sulfur content in samples, and Acid Neutralizing Capacity (ANC) is determined as kg $\mathrm{H}_{2} \mathrm{SO}_{4}$ /ton by titrating with $\mathrm{NaOH}$. Finally, Net Acid Producing Potential (NAPP = AP - ANC) is calculated with the results as the net value of AP and ANC. NAG test which was proposed in 1978 considers the maximum potential of acid production in rocks [6]. The potential is determined based on the change of $\mathrm{pH}$ in the solution when samples are dissolved by forced oxidation with $\mathrm{H}_{2} \mathrm{O}_{2}$ : the $\mathrm{pH}$ is reported as NAG pH. NAG pH and NAPP are plotted on graph to classify rocks into PAF or NAF [6] [7]. This classification was performed with the samples based on the results in this study. Besides, the amount of PAF and NAF in pit in area I and II was calculated as the ratio of the length of each representative sample to total length of them and with the result of classification.

Sequential extraction with acids was conducted with the samples taken both in pit and waste dump in order to discuss the occurrence of AMD within the waste dump. Sulfide minerals, such as pyrite, form sulfate with the progress of AMD [17]. Thus, the progress of AMD within the waste dump in the areas can be investigated through the comparison of the results of acid extraction that provides the amount of each form of $\mathrm{Fe}$ and $\mathrm{S}$ composing pyrite. The acids for extraction were selected in accordance with the method performed in the past [18] [19]. Each mineral is extracted at 3 stages of the extraction with $1 \mathrm{M} \mathrm{HCl}, 46 \% \mathrm{HF}$, and conc. $\mathrm{HNO}_{3}$. The time for agitation with shaker at the stage of extraction with $\mathrm{HNO}_{3}$ was changed from $2 \mathrm{~h}$ to $4 \mathrm{~h}$ to completely 
dissolve the samples. In this method, it was indicated that readily-soluble minerals such as sulfate and precipitates were extracted by $\mathrm{HCl}$, silicate minerals were extracted by $\mathrm{HF}$, and sulfide minerals were extracted with $\mathrm{HNO}_{3}$ [18]. The average amount of each form of Fe and S in area I and II was calculated based on the results in the same way as above.

\section{Results and Discussion}

\subsection{Possibility of Occurrence of Acid Mine Drainage (AMD)}

The amount of each type of rocks in pit was calculated as based on the results of classification of them into PAF, NAF, and uncertain in area I and II as shown in Figure 1 [8]. Most of the rocks were classified as PAF and NAF in each area for the results, and some of them were classified as uncertain rocks. PAF rocks are backfilled in waste dump as the cause of AMD, followed by setting a cover layer with NAF within the operation in mines. The rocks classified as uncertain rocks are also backfilled in waste dump in this mine as PAF within the operation to minimize the risk of AMD after mine closure. In light of the situation, it can be seen that same amount of PAF and NAF are produced in both areas in Figure 1 when the ratio of uncertain rocks is calculated as that of PAF: the ratio of PAF to NAF is nearly 1:1 in the areas. Moreover, similar proportion of PAF or NAF to the total is observed in area I and II in the case. These results indicated that more than $50 \%$ of waste rocks produced in the operation in the areas consisted of PAF assuming that uncertain rocks are PAF. They are similarly backfilled as PAF in the waste dump in the area, suggesting that a similar possibility of occurrence of AMD from the waste dump is presented in area I and II.

The average amount of Fe and S at each stage of the extraction in pit in area I and II is shown in Table 1. As seen in Table 1, Fe and $\mathrm{S}$ exist in the rock samples as three types of minerals, namely that they exist as the mineral extracted with $\mathrm{HCl}, \mathrm{HF}$, and $\mathrm{HNO}_{3}$. According to the previous research [18], readily-soluble minerals such as oxidation products and sulfate are obtained with $\mathrm{HCl}$ and refractory minerals such as sulfide minerals are extracted by $\mathrm{HNO}_{3}$ in this method. These minerals show different values of solubility rate, and it is important to discuss the occurrence of AMD in consideration of the reactivity of the minerals [20]. NAPP which is used to classify rocks into PAF and NAF in mines is calculated based on sulfur content in rocks: (NAPP = AP (total sulfur content $(\%) \times 30.6)-$ ANC) [6]-[8]. Net balance of acid potential and acid neutralizing capacity in rocks is evaluated by NAPP. These facts suggest that waste rocks in mines are classified by directly calculating total sulfur content in rocks without the consideration of the existing form of Fe and S the reactivity. The amount of

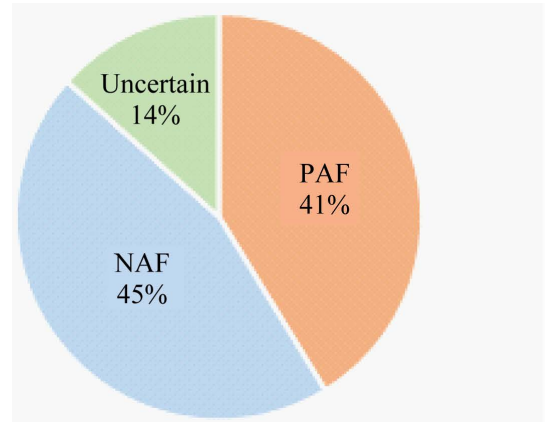

(a)

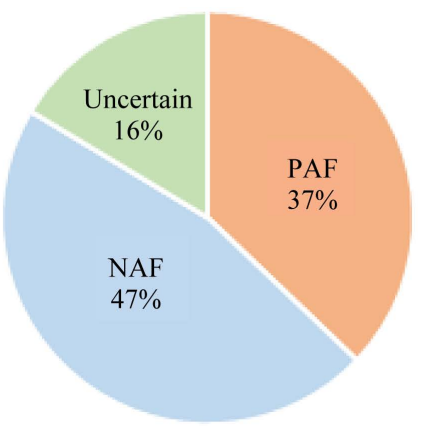

(b)

Figure 1. Ratio of the amount of PAF, NAF, and uncertain rocks. (a) Area I; (b) Area II.

Table 1. Average amount of each form of Fe and S in area I and II.

\begin{tabular}{ccccc}
\hline Area & $(\mathrm{mg} / \mathrm{g})$ & $\mathrm{HCl}$ & $\mathrm{HF}$ & $\mathrm{HNO}_{3}$ \\
\hline \multirow{2}{*}{ Area I } & $\mathrm{Fe}$ & 30.1 & 8.6 & 4.4 \\
& $\mathrm{~S}$ & 1.9 & 0.5 & 3.5 \\
\multirow{2}{*}{ Area II } & $\mathrm{Fe}$ & 16.3 & 10.3 & 3.1 \\
& $\mathrm{~S}$ & 0.8 & 0.8 & 2.1 \\
\hline
\end{tabular}


extracted $\mathrm{Fe}$ and $\mathrm{S}$ by $\mathrm{HNO}_{3}$ is slightly larger in area I than that in area II in Table 1 . There is not a large difference in the amount of extracted Fe and S with HF between the areas. The amount of extracted Fe and S with $\mathrm{HCl}$ is larger in area I than that in area II, especially the amount of extracted Fe. This indicates that there is a large amount of readily-soluble Fe and S in area I in comparison with that in area II. Red-brown precipitation which was considered ferric hydroxide was observed in waste water from the waste dump in area I as shown in Figure 2 while there was not such a precipitation in discharged water from the waste dump in area II [21]. Additionally, the possibility of occurrence of AMD over the long term may not be varied between the areas since there was not a large difference in the amount of PAF and Fe and $\mathrm{S}$ which exist as sulfide minerals contributing to AMD for a long term by gradual dissolution. A larger amount of soluble Fe and S in area I than that in area II resulted in red-brown precipitation in waste water from the waste dump in area I, indicating that the existing form of Fe and $\mathrm{S}$ has to be taken into account in discussion of occurrence of AMD over time.

\subsection{Backfill Conditions of Waste Rocks in Waste Dump}

The XRD patterns of the rocks in the waste dump from the surface down to $100 \mathrm{~cm}$ in area I and II are described in Figure 3. The presence of quartz and kaolinite were mainly observed at each depth in both areas, while a slight peak of pyrite appeared in both areas. The presence of kaolinite which is one of clay minerals was clearly observed, suggesting that clay-rich rocks are backfilled in the waste dump in area I and II. The peak of siderite $\left(\mathrm{FeCO}_{3}\right)$ was, besides, obtained in only area I. Considering that a large amount of readily-soluble Fe was leached by $\mathrm{HCl}$ from rocks in pin in area I in comparison with that in area II as described above and red-brown precipitation in waste water from the waste dump in only area I, the dissolution of the siderite with occurrence of AMD led to the precipitation with the red-brown color. There was no other significant difference in minerals in rocks in the waste dump.

Figure 4 shows the result of classification of waste rocks in the waste dump. All of the samples were classified as PAF at each depth in area I and II. It is evident that PAF rocks are backfilled until $100 \mathrm{~cm}$ depth in the waste dump in both areas for the result in addition to the presence of pyrite in XRD analysis. Regarding that the thickness of a cover layer with NAF is set at about from 1 to 5 min many cases [5] [9]-[11], it can be seen that PAF rocks are not backfilled at proper placement in the waste dump in area I and II, resulting in the failure of construction of a cover layer. Therefore, the failure obviously attributes to the failure of proper placement of cover materials by an operational problem by reference to the reasons in the case of the moisture store-andrelease concept in a cover layer [12].

NAPP at $20 \mathrm{~cm}$ intervals down to $100 \mathrm{~cm}$ depth in the waste dump in area I and II are presented in Figure 5. Similar values from 10 to $30 \mathrm{~kg} \mathrm{H}_{2} \mathrm{SO}_{4} /$ ton were observed at each depth in the areas. This suggests that the waste rocks backfilled in the waste dump still have acid potential contributing to AMD. Additionally, the results from the surface down to $40 \mathrm{~cm}$ depth showed similar value; meanwhile, that from the $40 \mathrm{~cm}$ depth to $100 \mathrm{~cm}$ showed a significant difference. It can be said for the result that there is not a great difference in acid potential in rocks in the waste dump from the surface down to $40 \mathrm{~cm}$ depth in terms of NAPP.

Figure 6 presents the correlation between the amount of extracted Fe and Sin rocks in the waste dump in area I and II at each stage of extraction with acids. The ratio of Fe:S mole at $\mathrm{HNO}_{3}$ stage was around 1:2 (correlation

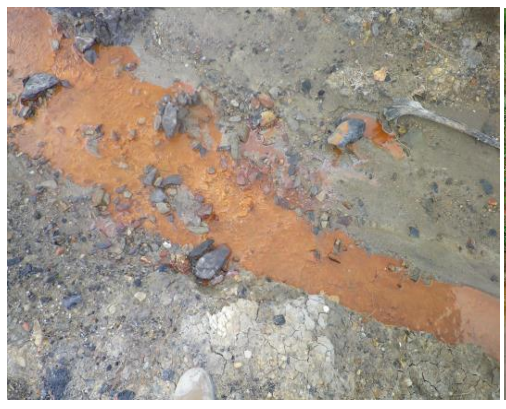

(a)

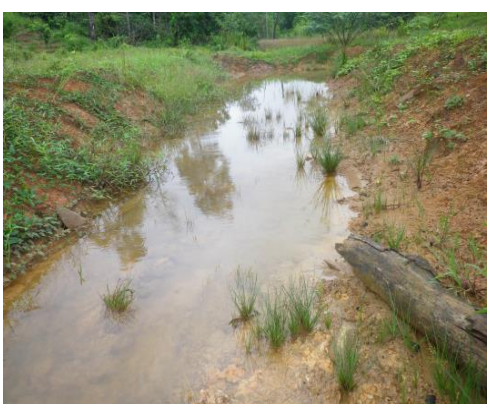

(b)

Figure 2. Waste water in the drainage from the waste dump. (a) Drainage at the base of the waste dump in area I; (b) Drainage at the base of the waste dump in area II. 


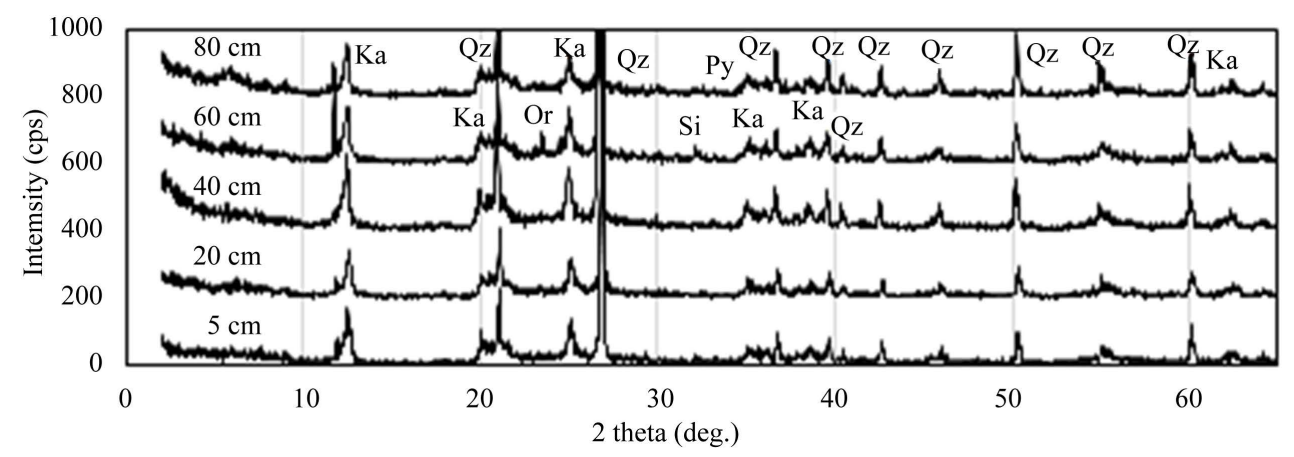

(a)

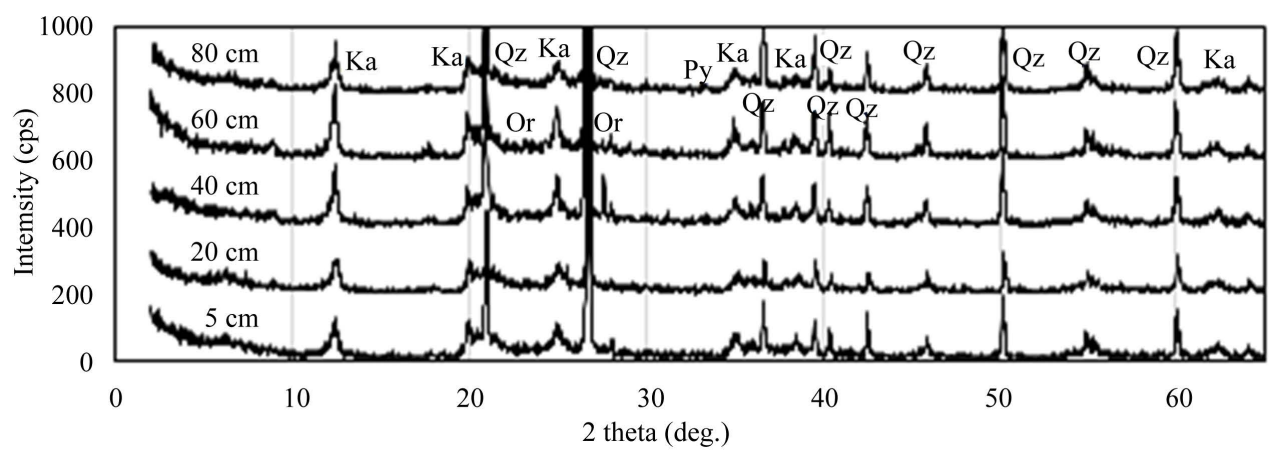

(b)

Figure 3. XRD patterns of rock samples at each depth in the waste dump. (a) Area I; (b) Area II. Ka: kaolinite, Qz: quarz, Or: orthoclase, Py: pyrite, Si: siderite.

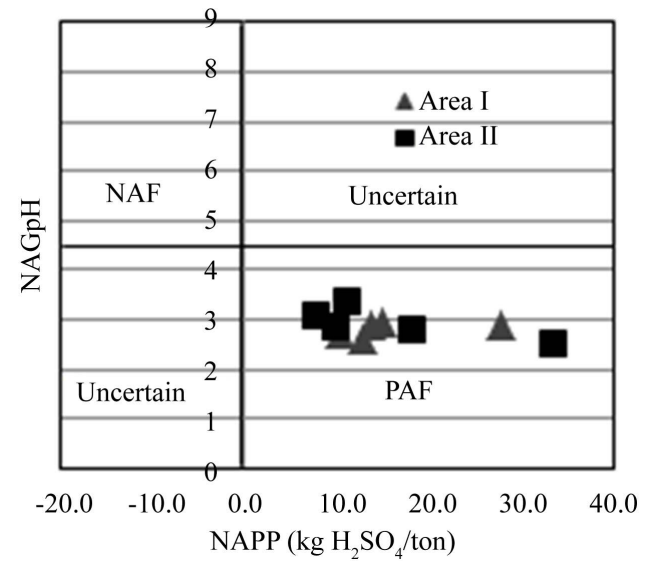

Figure 4. Classification of rock samples in the waste dump in area I and area II.

coefficient 0.9659$)$ nearly corresponding to that of pyrite $\left(\mathrm{FeS}_{2}\right)$ where as a good correlation was not observed at $\mathrm{HCl}$ and $\mathrm{HF}$ stage. Thus, pyrite was leached by $\mathrm{HNO}_{3}$ and readily-soluble minerals were extracted by $\mathrm{HCl}$ in this study [18]. The amount of both of $\mathrm{Fe}$ and $\mathrm{S}$ extracted with $\mathrm{HCl}$ and $\mathrm{HNO}_{3}$ were less in area II than that in area I in Figure 7. Similar values were obtained between the areas at the stage of extraction with HF. The amount of extracted Fe and S by $\mathrm{HCl}$ at each depth in area II was, moreover, less than 5.00 and $0.70 \mathrm{mg} / \mathrm{g}$, respectively. As discussed above, the average amount of Fe and $\mathrm{S}$ in rocks in pit extracted with $\mathrm{HCl}$ in area II was 16.3 and $0.8 \mathrm{mg} / \mathrm{g}$, respectively. The amount of extracted Fe and S in the waste dump was lower than that in pit for the results. In area I, the amount of extracted Fe and S in the waste dump was from 5.00 to $22.00 \mathrm{mg} / \mathrm{g}$ and from 0.50 to $2.60 \mathrm{mg} / \mathrm{g}$, respectively. They were less than the average amount of them in pit: that of $\mathrm{Fe}$ and $\mathrm{S}$ 


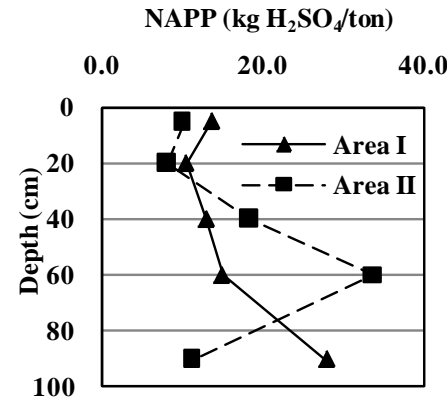

Figure 5. NAPP at each depth in area I and II.

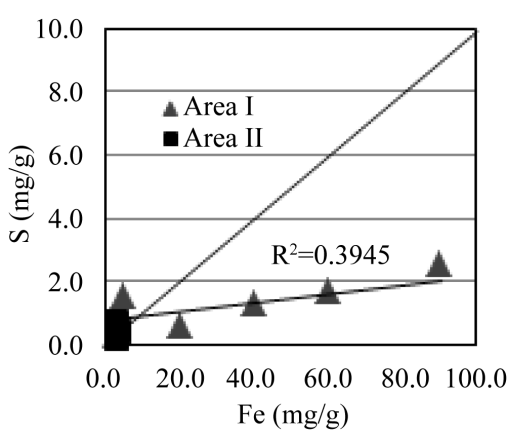

(a)

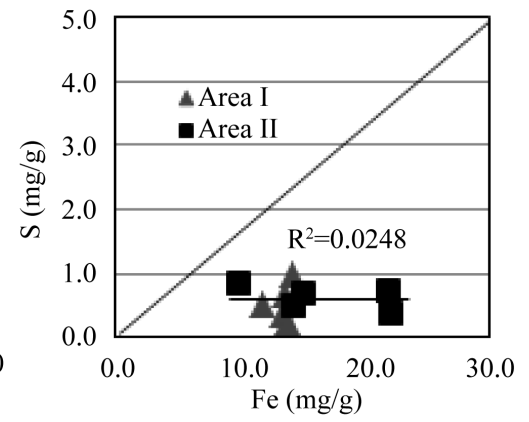

(b)

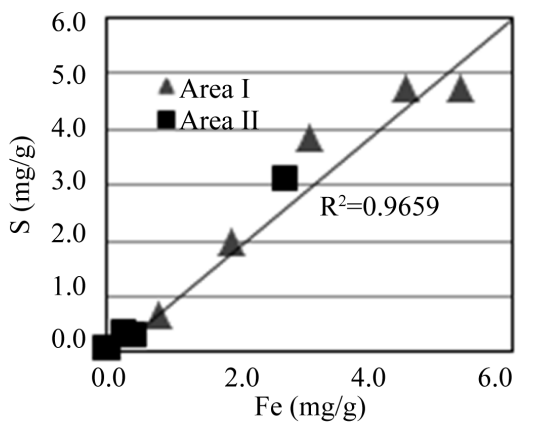

(c)

Figure 6. Correlation of extracted Fe and S at each stage of extraction in area I and II. (a) Extracted elements by HCl; (b) Extracted elements by HF; (c) Extracted elements by $\mathrm{HNO}_{3}$.

was 30.1 and $1.9 \mathrm{mg} / \mathrm{g}$, respectively. In short, the amount of Fe and S which exist as readily-soluble minerals decreased after the backfill in the waste dump. Considering that it has taken more than a year since the waste dump was constructed in area I and II, these minerals dissolved inside of the waste dump by infiltration of precipitation into the waste dump and flowed in waste water. Furthermore, the amount of extracted Fe and S with $\mathrm{HNO}_{3}$ was larger at each depth in area I than that in area II. The difference of them between the areas significantly increased from the surface down to $20 \mathrm{~cm}$ depth, and the amount of them in area II was nearly zero. This may be attributed to the dissolution of sulfide minerals in the layer in area II inside of the waste dump for the results since there was not a large difference in the amount of sulfide minerals extracted by $\mathrm{HNO}_{3}$ between the areas in pit before backfilling in waste dump as discussed above. Sulfate is formed by the reaction of pyrite with oxygen and water and iron dissolves in water in the form of ferrous or ferric ion as AMD proceeds [2] [12]. It is suggested that this reaction remarkably progressed in area II in the layer until $20 \mathrm{~cm}$ depth in comparison with the condition in area I, leading to the low value of the amount of sulfide minerals in the layer in area II. Moreover, this indicated that the occurrence of AMD progressed at different rates in the waste dump in area I and II. Given that there was not a significant difference in the possibility of occurrence of AMD before backfilling and in the climate in area I and II, the difference of physical properties in the surface layer of the waste dump likely caused the conditions. Physical property such as permeability and saturation condition in a cover layer is one of the important factors which affect the progress of AMD inside of waste dump [22]. Although it is not discussed in terms of physical characteristics of rocks in a cover layer in this study, this infers that the difference of physical properties in a cover layer in the areas has to be considered in order to discuss the progress of AMD inside of waste dump from a point of the performance of a cover layer.

As demonstrated above, it was observed that there was not a great difference in acid potential in rocks in the waste dump until $40 \mathrm{~cm}$ depth in area I and II from the point of NAPP. However, acidic water can occur from the surface layer in area I due to the presence of sulfide minerals; on the other hand, it cannot occur for a long term from the layer until $20 \mathrm{~cm}$ depth in area II since the amount of sulfide minerals indicated nearly zero. AMD can, nevertheless, occur from the deeper layer with sulfide minerals when oxygen and water infiltrate in the waste dump in area II. Thus, the progress of AMD in the waste dump should be discussed by considering not only geochemical properties such as NAPP but also the form of Fe and S. 

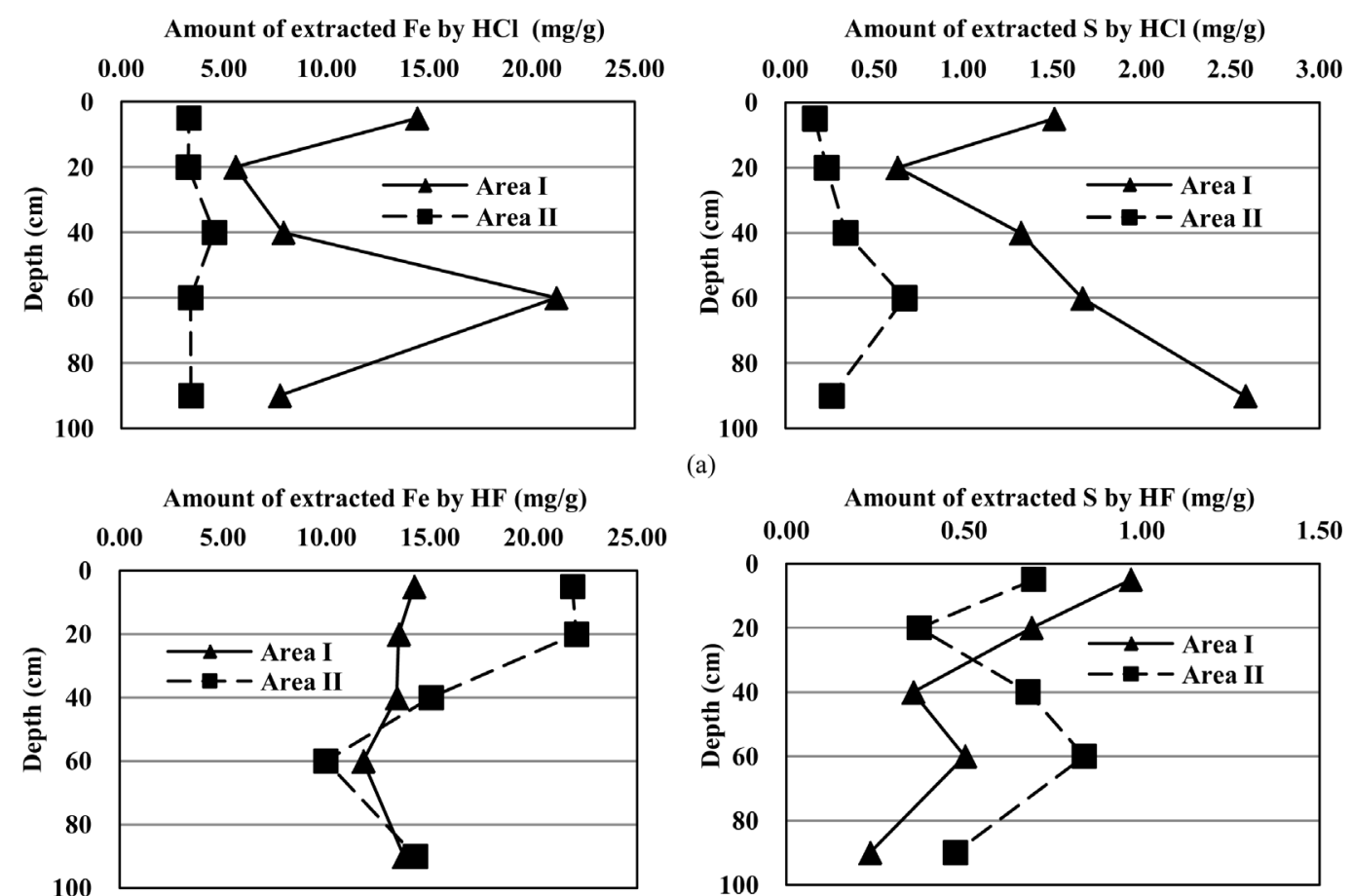

(a)

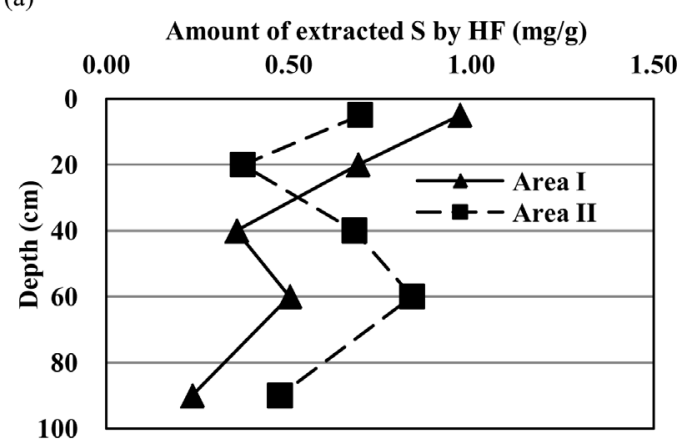

(b)


(c)

Figure 7. Amount of extracted Fe and S at each depth in area I and II. (a) Extracted elements by HCl; (b) Extracted elements by HF; (c) Extracted elements by $\mathrm{HNO}_{3}$.

It became evident that about $40 \%$ of waste rocks in pit consisted of PAF in the areas in this study. Furthermore, the backfill of PAF in the surface layer until $100 \mathrm{~cm}$ depth in the waste dump in both areas was contrary to the concept of cover system in which a cover layer is constructed with NAF. The cause of the failure of constructing a cover layer was not clearly elucidated by only the results in this study, leastwise attributed to the shortage of NAF and/or the failure of proper placement of cover rocks by operational problems. The case that up to $80 \%$ of waste rocks consist of PAF and it may make it difficult to construct a cover layer was reported in Indonesia in the past research [16]. For these reasons, the field investigation on the construction of cover system in terms of the amount and types of waste rocks, chemical and physical characteristics of rocks, and operational process in mines has to be conducted for the successful construction of a cover layer.

\section{Conclusion}

The main conclusions are summarized as follows: NAPP of waste rocks in the waste dump in area I and II was from 10 to $30 \mathrm{~kg} \mathrm{H}_{2} \mathrm{SO}_{4}$ /ton, suggesting that PAF rocks were backfilled in a cover layer. Additionally, the ratio of PAF in waste rocks in pit was $40 \%$ in the areas. The backfill of PAF in a cover layer in the areas in this mine was contrary to the concept of cover system in which a cover layer should be constructed with NAF. The cause 
of the failure of constructing a cover layer can be attributed to the shortage of NAF and/or the failure of proper placement of cover rocks by operational problems in this study. A larger amount of readily-soluble Fe and S in the waste dump in area I in comparison with that in area II, moreover, resulted in red-brown precipitation in the area. This suggested that the form of Fe and $\mathrm{S}$ has to be taken into account to discuss the occurrence of AMD over time. Furthermore, AMD progressed at different rates in the waste dump in area I and II, especially until 20 $\mathrm{cm}$ depth. This may be attributed to the difference in physical properties of a cover layer. Hence, the cause of the difference in the progress of AMD inside of the waste dump should be discussed from a point of the physical properties contributing to the performance of a cover layer.

\section{Acknowledgements}

The authors are grateful to the Mitsui Matsushima Co., Ltd. for financial support. The authors would like to ex-press their gratitude and appreciation to the mine for providing the rock samples and for kind assistance with fieldwork.

\section{References}

[1] Jennings, S.R., Neuman, D.R. and Blicker, P.S. (2008) Acid Mine Drainage and Effects on Fish Health and Ecology: A Review. Reclamation Research Group Publication, Bozeman, 1-26. http://reclamationresearch.net/publications/Final_Lit_Review_AMD.pdf

[2] Singh, G. and Bhatnagar, M.M. (1988) Inhibition of Bacterial Activity in Acid Mine Drainage. International Journal of Mine Water, 7, 13-26. http://dx.doi.org/10.1007/BF02505389

[3] O’Kane, M. and Wels, C. (2003) Mine Waste Cover System Design-Linking Predicted Performance to Groundwater and Surface Water Impacts. Proceedings of the 6th International Conference for Acid Rock Drainage, Queensland, 12-18 July 2003, 341-349.

[4] Wilson, G.W., Williams, D.J. and Rykaart, E.M. (2003) The Integrity of Cover Systems-An Update. Proceedings of the 6th International Conference for Acid Rock Drainage, Queensland, 12-18 July 2003, 445-451.

[5] Shimada, H., Kusuma, G.J., Hiroto, K., Sasaoka, T., Matsui, K., Gautama, R.S. and Sulistianto, B. (2012) Development of a New Covering Strategy in Indonesia Coal Mines to Control Acid Mine Drainage Generation: A LaboratoryScale Result. International Journal of Mining, Reclamation and Environment, 26, 74-89. http://dx.doi.org/10.1080/17480930.2011.608505

[6] Sobek, A.A., Schuller, W.A., Freeman, J.R. and Smith, R.M. (1978) Field and Laboratory Methods Applicable to Overburdens and Minesoils. Report EPA-600/2-78-054, US National Technical Information Service Report PB-280, 495. http://www.osmre.gov/resources/library/ghm/FieldLab.pdf

[7] Miller, S., Robertson, A. and Donahue, T. (1997) Advances in Acid Drainage Prediction Using the Net Acid Generation (NAG) Test. Proceedings of the 4th International Conference on Acid Rock Drainage, Vancouver, 31 May-6 June 1997, 533-549.

[8] AMIRA International (2002) ARD Test Handbook: Prediction \& Kinetic Control of Acid Mine Drainage, AMIRA P387A. Ian Wark Research Institute and Environmental Geochemistry International Ltd., Melbourne. http://www.amira.com.au/documents/downloads/P387AProtocolBooklet.pdf

[9] Bonstrom, K., Allen, G., O’Kane, M. and Christensen, D. (2012) Evolution of Cover System Design and Waste Rock Management at a Mine in the Pilbara Region of Western Australia. Proceedings of the 7th International Conference on Mine Closure, Brisbane, 25-27 September 2012, 1-13.

[10] Lamoureux, S., Straker, J., Barbour, L. and O’Kane, M. (2012) Enhancing the Understanding for the Influence of Vegetation on Cover System Performance in a Canadian Mining Context. Proceedings of the 9th International Conference on Acid Rock Drainage, Ottawa, 20-26 May 2012.

[11] Bonstrom, K.L., Chapman, D., Swain, D. and O’Kane, M. (2009) Staged Approach to Closure of a Tailings Storage Facility in the Kimberly, Western Australia. Proceedings of the Mine Closure 2009 Conference, Perth, 9-11 September 2009, 65-78.

[12] O’Kane, M. and Ayres, B. (2012) Cover Systems That Utilize the Moisture Store-and-Release Concept-Do They Work and How Can We Improve Their Design and Performance? Proceedings of the 7th International Conference on Mine Closure, Brisbane, 25-27 September 2012, 1-9.

[13] Ayres, B. and O’Kane, M. (2013) Design, Construction, and Performance of Closure Cover Systems for Spent Heap Leach Piles-A State-of-the-Art Review. Proceedings of the Heap Leach Conference, Vancouver, 22-25 September 2013, 1-12. 
http://www.okc-sk.com/wp-content/uploads/2013/09/Ayres-and-OKane-2013-Design-construction-and-performance-of -closure-cover-systems-for-spent-heap-leach-piles.pdf

[14] Shurniak, R. and O'Kane, M. (2012) Soil-Plant-Atmosphere Numerical Modelling of a Cover System in NW Australia Utilizing the Moisture Store-and-Release Concept-Simulation of Seven Years of Field Performance Monitoring. Proceedings of the 9th International Conference on Acid Rock Drainage, Ottawa, 20-26 May 2012, 479-493.

[15] Matsumoto, S., Shimada, H., Sasaoka, T., Kusuma, J.G. and Gautama, S.R. (2015) The Key Factors for the Improvement of Classification Method of Waste Rocks Aimed at the Prevention of Acid Mine Drainage. Proceedings of the 5th International Symposium on Mineral Resources and Mine Development, Aachen, 27-28 May 2015, 473-486.

[16] Gautama, S.R., Kusuma, J.G., Abfertiawan, S.M., Wiedhartono, A., Gunawan, F., Lestari, L., Simbolon, R. and Diana, R.M. (2013) Study on Capping Options for Overburden Encapsulation to Prevent Acid Mine Drainage in Lati Coal Mine, Kalimantan, Indonesia. Proceedings of the Annual International Mine Water Association Conference: Reliable Mine Water Technology, Colorado, 5-9 August 2013, 341-347.

[17] Johnson, D.B. and Hallberg, K.B. (2003) The Microbiology of Acidic Mine Waters. Research in Microbiology, 154, 466-473. http://dx.doi.org/10.1016/S0923-2508(03)00114-1

[18] Sasaki, K., Haga, T., Hirajima, T., Kurosawa, K. and Tsunekawa, M. (2002) Distribution and Transition of Heavy Metals in Mine Tailing Dumps. Materials Transactions, 43, 2778-2783. http://dx.doi.org/10.2320/matertrans.43.2778

[19] Huerta-Diaz, M.A. and Morse, J.W. (1990) A Quantitative Method for Determination of Trace Metal Concentrations in Sedimentary Pyrite. Marine Chemistry, 29, 119-144. http://dx.doi.org/10.1016/0304-4203(90)90009-2

[20] Parbhakar-Fox, A. and Lottermoser, B.G. (2015) A Critical Review of Acid Rock Drainage Prediction Methods and Practices. Minerals Engineering, 82, 107-124. http://dx.doi.org/10.1016/j.mineng.2015.03.015

[21] Luptakova, A., Prascakova, M. and Kotulicova, I. (2012) Occurrence of Acidithiobacillus ferrooxidans Bacteria in Sulfide Mineral Deposits of Slovak Republic. Chemical Engineering Transactions, 28, 31-36.

[22] Kusuma, J.G., Shimada, H., Sasaoka, T., Matsui, K., Nugraha, C., Gautama, S.R. and Sulistianto, B. (2012) Physical and Geochemical Characteristics of Coal Mine Overburden Dump Related to Acid Mine Drainage Generation. $\mathrm{Me}$ moirs of the Faculty of Engineering, 72, 23-38. 